Available online at GSC Online Press Directory

GSC Biological and Pharmaceutical Sciences

e-ISSN: 2581-3250, CODEN (USA): GBPSC2

Journal homepage: https://www.gsconlinepress.com/journals/gscbps

(RESEARCH ARTICLE)

\title{
Surface bacterial flora of Tilapia (Oreochromis niloticus) in open markets of Yenagoa, Bayelsa state
}

\author{
Alagoa Koru Joe $1^{*}$, Daworiye Pereowei ${ }^{2}$, Enaregha Esther ${ }^{2}$, Ipiteikumoh Bekewei ${ }^{2}$ and Agwu Rita ${ }^{1}$ \\ ${ }^{1}$ Department of Biological Sciences, Niger Delta University, Amassoma, Bayelsa State. \\ 2 Faculty of Science, Isaac Jasper Boro College of Education, Sagbama, Bayelsa State.
}

Publication history: Received on 29 June 2018; revised on 14 July 2018; accepted on 16 July 2018

Article DOI: https://doi.org/10.30574/gscbps.2018.4.2.0057

\begin{abstract}
Surface bacterial flora of Tilapia in open markets of Yenagoa, Bayelsa State was investigated in order to ascertain their pathogen content, natural toxins and other possible contaminants which is a major cause of diarrhea disease, illness and deaths worldwide. Nine (9) Tilapia fish were obtained from each of three open markets located at Swali, Kpansia and Tombia in Yenagoa. The fish were put in different plastic bags tagged and transported to the Biological science laboratory of the Niger Delta University, Amasoma, Bayelsa State. Swab specimens were then taken from each fish and a stock solution was prepared for each fish specimen. Slide samples for each stock solution were made and analyzed using an electron microscope with magnification of 3000x. Result reveals that the bacteria streptococci, staphylococci were present in all fish samples. There were significant differences in bacterial load in the three different markets in Yenagoa. Based on observation from this study, it can be concluded that fresh fish in Yenagoa pose a serious health risk if consumed without proper washing and cooking.
\end{abstract}

Keywords: Surface bacteria; Flora, Tilapia; Open market; Yenagoa

\section{Introduction}

Fish play a significant role in our diet, providing over $60 \%$ of animal source food, representing a crucial source of micronutrients, and possessing an extremely strong cultural attachment [1, 2]. Unfortunately, a large amount of fish spoils each year in the country due to the growth and activity of pathogenic microorganisms [3].

Therefore, malnutrition remains a significant development challenge; fish is an irreplaceable diet for most people. [4]. The quality of fish mainly depends on the time between the harvesting and processing periods. At the time of capture, fresh fish contain on their bodies a wide variety of microorganisms also known as microflora of the fish [5]. Also during handling of the commodity, the natural flora of the environment may be contaminated with organisms associated with man such as members of the enterobacteriaceae and Staphylococcus aureus which can grow well at 30-37 ${ }^{\circ} \mathrm{C}[6,7]$.

Furthermore, fish or frozen fish may be contaminated with different types of bacteria such as Salmonella, Coliform, fecal Coliform, Streptoccoci, and Staphylococcus aureus and these are responsible for causing different food borne diseases [8]. The microbiological qualities of these species are important to consumers as well as fish processors and public health authorities $[9,10]$. This study was therefore initiated because of concerns about food security and public health.

\footnotetext{
${ }^{*}$ Corresponding author

E-mail address: mrkjalagoa@yahoo.com
}

Copyright (C) 2018 Author(s) retain the copyright of this article. This article is published under the terms of the Creative Commons Attribution Liscense 4.0. 


\section{Material and methods}

\subsection{Sample collection}

Nine (9) dead Tilapia (Oreochromis niloticus) fish were bought from three (3) different selective markets located at Opolo, Tombia and Swali in Yenagoa Local Government Area. They were transported with the help of a sterile bucket containing ice pack to the microbiology laboratory of the Niger Delta University and stored in a refrigerator for Bacterial analysis.

\subsection{Experimental design}

The Tilapia (Oreochromis niloticus) fish were divided into three (3) experimentally groups, sample 1, sample 2 and sample 3, each sample made up of three fish representative of the different market.

\subsection{Preparation of sample}

Each Tilapia (Oreochromis niloticus) fish from sample 1, sample 2 and sample 3 were introduced into separate $10 \mathrm{~m}$ of prepared normal saline. A surface sterilized spatula was then used to repeatedly turn the fish over to enable adequate immersion. From this stock solution, a nine fold serial dilution was carried out and used for inoculation. $1 \mathrm{~m}$ of serial diluted factor 10 each from samples were plated in triplicate into prepared agar and incubated at $37{ }^{\circ} \mathrm{C}$ for 24 hours. Six (6) pure isolates in a ratio 2:2:2 each from sample treatment of the different market were re-cultured as pure isolate for identification.

\subsection{Preparation of media}

Since various biochemical tests are used in identifying isolated bacteria colonies, differential media were not used in this study. The media used however, was nutrient agar. Nutrient agar is a general purpose media used for growing a wide range of non-fastidious (non-selective) organisms.

\subsubsection{Nutrient agar}

It is composed of the following; peptone (0.5\%), beef extract/yeast extract ( $0.3 \%)$, agar (1.5\%), Sodium chloride (0.5\%), Distilled water, PH adjusted to neutral level (6.8). Nutrient agar was prepared for use according to manufacturer's instructions; $28 \mathrm{~g}$ of nutrient agar was transferred into a conical flask containing $100 \mathrm{ml}$ of distilled water. The medium was then left to soak for 10 minutes before swirling to dissolve property.

\subsubsection{Sterilization}

After tightly capping the flask with cotton wool and foil, the media as well as other glassware's to be used were sterilized by autoclaving at $121^{\circ} \mathrm{C}$ for 15 minutes. It was then allowed to cool to a temperature of $47^{\circ} \mathrm{C}$ before being used.

\subsubsection{Inoculation and isolation of bacteria}

In this method, $0.1 \mathrm{ml}$ of prepared specimens from selected dilution factor was introduced into sterile petri dish. And molten agar was then poured into it. Inoculated plates containing molten agar was then swirled over the work bench and allowed to solidify before being inverted and incubated.

\subsubsection{Viable count of bacteria}

After 24 hours of incubation, the numbers of isolated bacteria were counted using a colony counter. The number of viable bacteria cells in the specimen was then ascertained by calculating the bacteria CFU.

\subsubsection{Maintenance of pure cultures}

Streak plate method was used in isolating bacteria cells into pure culture. Bacteria colonies that appeared on nutrient agar (NA) plates were sub-cultured aseptically by streaking into newly prepared agar slant bottles containing sterile media. Slant bottles containing isolated bacteria cell were then incubated for 72 hours at room temperatures, after which they were stored in a refrigerator to preserve cell viability for identification and further use. 


\subsubsection{Identification of bacteria}

Cultured isolates of bacteria cells were characterized and identified by using biochemical tests, as well as observing the characteristic colony morphology of bacteria colonies. Gram staining was also carried out on bacteria isolates to ascertain their response to gram staining.

\subsubsection{Morphological characteristics}

The morphological characteristics of isolated bacteria colonies on growth media were observed after growth. Few of the morphological characteristics observed were those relating to bacteria colony shape, color, texture, elevation and margin.

\subsubsection{Gram staining}

This procedure is based on the principle that gram positive bacteria retains the primary staining color of crystal violet dye after decolorizing with acetone or alcohol to appear as deep violet when viewed under the light microscope. Gram negative bacteria on the other hand do not retain any characteristic crystal violet dye coloration upon de-colorization.

In this procedure, a thin smear of bacteria isolate was made on a clean glass slide using a sterile wire loop to transfer a small portion of distilled water unto the slide and aseptically transferring a portion of bacteria isolate to the slide and gently smearing into the water. The smear was then air dried and heat fixed by quickly passing the slide two to three times through a Bunsen burner flame. The smear was then flooded with crystal violet and allowed to stand for one minute before being gently washed off with tap water. The smear was again flooded with lugos iodine solution and allowed to stand for one minute before being again gently washed off with tap water. 95\% alcohol was then used to decolorize the dyes before being washed by gently flooding the smear with tap water. Safranin was poured over the smear and allowed for one minute before being washed with running tap water and allowed to air dry. The smear was then observed under oil immersion with (100x) objective using a light microscope.

\subsection{Biochemical tests}

Some biochemical tests used to identity bacteria isolates include catalase, coagulase, indole, motility, and oxidase. These tests create a platform from which isolated bacteria colonies were identified.

\subsubsection{Catalase test}

A loopful of 3\% hydrogen peroxide was transferred unto a clean glass slide, and a small portion of selected bacteria of pure culture was smeared onto the drop of hydrogen peroxide. An observed bubbling effect indicates oxygen gas production. Such organism is said to be catalase positive [11].

\subsubsection{Coagulase test}

Coagulase is an enzyme that clots blood plasma. It is produced by Staphylococcus aureus. This test differentiates Staphylococcus aureus from other coagulase negative staphylococcus species. This enzyme clots blood plasma by converting soluble fibrinogen (in plasma) to insoluble fibrin.

In this procedure, blood plasma was dropped on a grease free glass slide, and the bacteria isolate was aseptically smeared on it using a sterile wire loop. Clothing indicates positive result, while non-clotting indicates organisms without coagulase enzyme, and are therefore termed negative.

\subsubsection{Oxidase test}

This test is used to identity organisms capable of producing the enzyme cytochrome oxidase. Cytochrome oxidase transfers electrons from electron transport chain to oxygen, reducing it to water. This test is commonly used to distinguish between oxidase negative enterobacteriaceae, and oxidase positive pseudomadaceae. In this procedure, 1.1 $\mathrm{g}$ of oxidase reagent (tetra-methyl-p-phenylene diamine dehydrochloride) was dissolved in $10 \mathrm{ml}$ of distilled water, which was added into filter paper in a petri dish. The isolated test culture was then smeared unto the filter paper using a glass Rod. A positive result shows the development of dark purple color within 10 seconds.

\subsubsection{Indole test}

Indole test is used to determine the ability of an organism to split the amino-acid tryptophan to form the compound indole. In this test, $10 \mathrm{~g}$ of peptone and $8 \mathrm{~g}$ of sodium chloride were dissolved in 1 litter of distilled water. It was then heated and dispensed to the test tubes and sterilized. The isolates were inoculated into the test tubes and incubated at 
$37{ }^{\circ} \mathrm{C}$ for 2-5 days. About 2-3 drops of kovac's reagent was then added into the test tubes. The appearance of a red layer or red ring on the culture indicates a positive result.

\subsubsection{Motility test}

This test was used to determine if an organism is equipped with flagella and is thus capable of swimming away from a stab mark. This procedure was carried out making use of sulphide indole motility medium. The medium was dispersed into test tubes and sterilized. After cooling, pure culture isolates were inoculated into the liquid molten media and incubated at $37^{\circ} \mathrm{C}$ for 2-4 days. Motile organisms grow diffusely from the top to the bottom of the test tubes, while nonmotile organisms only grow at the top of the medium.

\section{Results}

Table 1 Bacteria colony count in $\mathrm{CFU} / \mathrm{ml}$ from the fish sample, cultured in nutrient agar

\begin{tabular}{lllll}
\hline $\begin{array}{l}\text { Sample Stations } \\
\text { (Markets) }\end{array}$ & Replicates & $\begin{array}{l}\text { Sample 1 } \\
\text { (cfuml) }\end{array}$ & $\begin{array}{l}\text { Sample 2 } \\
\text { (cfuml) }\end{array}$ & $\begin{array}{l}\text { Sample 3 } \\
\text { (cfuml) }\end{array}$ \\
\hline Tombia & $\mathrm{R}_{1}$ & $138 \times 10^{3}$ & $180 \times 10^{3}$ & $146 \times 10^{3}$ \\
& $\mathrm{R}_{2}$ & $150 \times 10^{3}$ & $175 \times 10^{3}$ & $136 \times 10^{3}$ \\
& $\mathrm{R}_{3}$ & $140 \times 10^{3}$ & $197 \times 10^{3}$ & $159 \times 10^{3}$ \\
Opolo & $\mathrm{R}_{1}$ & $142 \times 10^{3}$ & $170 \times 10^{3}$ & $175 \times 10^{3}$ \\
& $\mathrm{R}_{2}$ & $144 \times 10^{3}$ & $168 \times 10^{3}$ & $179 \times 10^{3}$ \\
& $\mathrm{R}_{3}$ & $130 \times 10^{3}$ & $194 \times 10^{3}$ & $161 \times 10^{3}$ \\
Swali & $\mathrm{R}_{1}$ & $164 \times 10^{3}$ & $100 \times 10^{3}$ & $152 \times 10^{3}$ \\
& $\mathrm{R}_{2}$ & $158 \times 10^{3}$ & $189 \times 10^{3}$ & $167 \times 10^{3}$ \\
& $\mathrm{R}_{3}$ & $153 \times 10^{3}$ & $173 \times 10^{3}$ & $148 \times 10^{3}$ \\
\hline
\end{tabular}

Table 2 Mean and standard deviation for the colony forming unit measured in CFU/ml and biochemical identified bacterial species

\begin{tabular}{|c|c|c|c|c|c|c|}
\hline $\begin{array}{l}\text { Market } \\
\text { Location }\end{array}$ & Sample 1 & Sample 2 & Sample 3 & $\begin{array}{l}\text { No of pure } \\
\text { isolate }\end{array}$ & $\begin{array}{l}\text { Identified } \\
\text { species }\end{array}$ & Bacterial \\
\hline \multirow[t]{4}{*}{ Tombia } & & & & & \multicolumn{2}{|c|}{ Escherichia coli (1) } \\
\hline & $146.6 \pm 3.5^{\mathrm{a}}$ & $171.8 \pm 9.6^{b}$ & $160.3 \pm 4.5^{\mathrm{ab}}$ & 6.0 & \multirow{2}{*}{\multicolumn{2}{|c|}{$\begin{array}{l}\text { Staphylococcus sp. (3) } \\
\text { Bacillus sp. (2) }\end{array}$}} \\
\hline & & & & & & \\
\hline & & & & & \multicolumn{2}{|c|}{ Staphylococcus sp. (1) } \\
\hline \multirow[t]{4}{*}{ Opolo } & $137.0 \pm 7.0^{\mathrm{a}}$ & $181.3 \pm 13.0^{\mathrm{b}}$ & $170.0 \pm 9.0^{\mathrm{ab}}$ & 6.0 & \multicolumn{2}{|c|}{ Bacillu sp. (2) } \\
\hline & & & & & \multicolumn{2}{|c|}{ Escherichia coli (2) } \\
\hline & & & & & \multicolumn{2}{|c|}{ Enterobacter sp. (1) } \\
\hline & & & & & \multicolumn{2}{|c|}{ Staphylococcus sp. (2) } \\
\hline \multirow[t]{3}{*}{ Swali } & $155.5 \pm 2.5^{\mathrm{a}}$ & $181.7 \pm 8.0^{\mathrm{b}}$ & $157.5 \pm 9.5^{\mathrm{ab}}$ & 6.0 & \multicolumn{2}{|c|}{ Bacillus sp. (1) } \\
\hline & & & & & \multicolumn{2}{|c|}{ Enterobacter sp. (1) } \\
\hline & & & & & \multicolumn{2}{|c|}{ Escherichia coli (2) } \\
\hline
\end{tabular}

$a^{*} b^{*} c$ Means significant difference within parameters at alpha level $p<0.05$

A significant different was recorded between sample groups 1 and 2 at $p<0.05$, but no significant difference $(p>0.05)$ was recorded between sample 1 and 3 or 2 and 3 among the surface bacterial associated with the fish specimen. All the bacterial isolated belong to the family enterobacteriaceae, except staphylococcus $s p$. and bacillus $s p$. which belong to staphylococcaceae and bacillaceae family respectively. 


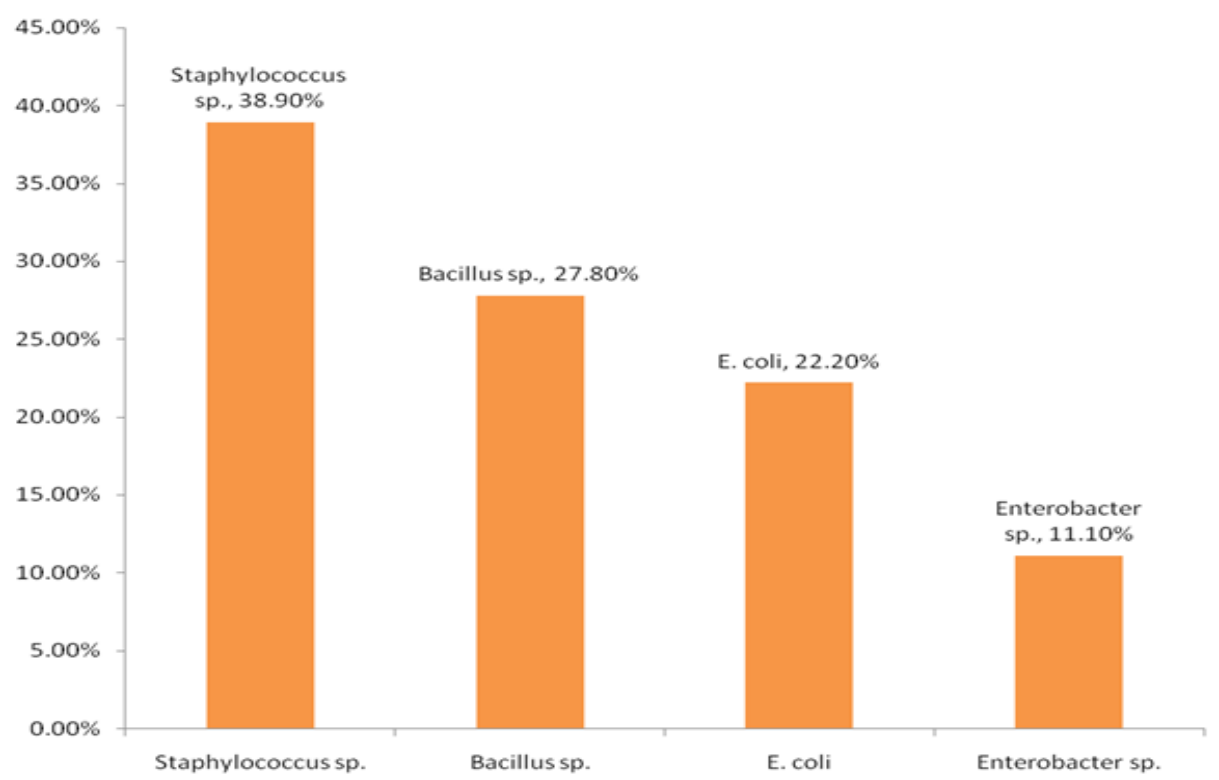

Figure 1 The percentage prevalence of surface bacteria from Tilapia fish

\section{Discussion}

The findings of the study revealed the isolates were gram positive and Gram negative bacteria: Staphylococcus sp., Escherichia coli, Bacillus sp., and: Enterobacter sp. respectively. This shows contamination of the fish caused by the source, handling, mode of preservation and environmental factors. The study of bacteriological analysis from tilapia fish also revealed the presence of possible pathogenic micro-organisms as well as coliform bacterial counts from fish samples which is in accordance with the findings of [12] and does not corresponds with the work by [13-14], that isolated Pseudomonas spp, Aeromonas spp and Salmonella spp.

A total of 18 isolates comprising of 4 different genera of gram positive and gram negative bacteria were isolated (Table 2 ) in this study with incident rates of $11.1 \%, 22.2 \%, 27.8 \%$, and $38.9 \%$ in each species across the markets. This showed that all markets contributed equally to the microbial diversity. The bacteria isolates were identified as Staphylococcus spp, Bacillus spp, Escherichia coli and Enterobacter spp by comparing their morphological and biochemical characteristics with standard reference organisms $[15,11]$. Microorganisms isolated from the fish samples in this study have been earlier found in foods, environment and other places, and their pattern is similar to previous reports [1623].

The findings of this study also agrees to reports of Okonko et al. [20-23], were they isolated almost similar organisms from water, seafood products and seafood processors. While Enabulele and Uraih [16], were different from this study which reported high prevalence rate of $E$. coli in fish samples in an open market each, recording $88.8 \%$ and $100 \%$. coli respectively. Also Clarence et al., [18] and Oyeleke [19] reported mixed species of bacteria such as $S$. aureus, E. coli, Bacillus spp, Enterobacter, Pseudomonas and Klebsiella in fish and fish products respectively with high prevalence.

Most of the organisms found in this study are those commonly found in soil and water. The presence of $E$. coli, and Enterobacter spp in this fish samples is an indication of fecal contamination of the fishes. This might be due to possible contamination of fresh fish itself during sales or unhygienic handling of the fish right from the catch or due to contamination from the skin, mouth, or nose of the handlers which can be introduced directly into foods by process line workers, and arms coming into contact with the food, or by coughing and sneezing [17, 20-23].

The isolation of Enterobacter spp. may be as a result of poor environmental conditions due to dust and contamination of the water used during catch and the container used in storing the fish after catch because Enterobacter spp. are also inhabitants of fish products, as reported by Talaro and Talaro [24]. Staphylococcus spp, and others found in the fish are also a pathogenic organism of public health significance and concerns $[20,21]$. This result is in accordance to the assertion of Okonko et al $[20,21,23]$ that improper handling and improper hygiene might lead to the contamination of ready to eat foods and this might eventually affects the health of the consumers. This was illustrated by the presence of the indicator organisms. 
Incidences of E. coli, Enterobacter spp and other index of poor sanitary quality found in this study are in agreement with previous studies. E. coli outbreaks due to plants and animal produce have become increasingly common [25]. While half of produce associated outbreaks were due to kitchen level cross contamination, which calls for further prevention efforts targeting food preparers, the other half were due to produce already contaminated with $E$. coli before purchase [25].

\section{Conclusion}

The results indicate that Staphylococcus was predominantly present in samples of local fish markets in Yenagoa. The poor quality may be due to poor handling, improper storage system and sanitary condition at all the steps in the fish processing and selling. The isolation of E. coli spp from the collected fish samples as potential pathogenic bacteria for human and as an indicator of food quality as spoilage organism. The presence of indicator and other organisms examined in this study is of special concern and perhaps the greatest danger associated with fresh fish used for food preparation, eating purposes and for other human consumption is contamination. It demonstrates a potential health risk as the organism is pathogenic and causes complications in children.

\section{Compliance with ethical standards}

\section{Acknowledgments}

We express our sincere thanks and appreciation to the entire laboratory crew of the Department of Biological Sciences, Niger Delta University, Amassoma, Bayelsa State, Nigeria for their expertise and commitment in this research.

\section{Conflict of Interest Statement}

We the authors (Alagoa, Koru Joe, Daworiye, Pereowei, Enaregha, Esther, Ipiteikumoh, Bekewei and Agwu, Rita) hereby certify that we have no affiliation with or involvement in any organization or entity with any financial interest (such as honoraria, educational grants; participation in speakers bureaus; membership; consultancies; stock ownership or other equity interest; and other expert testimony or patent licensing arrangement) or non- financial interest in the subject matter or materials discussed in this manuscript. The authors also declare that we do not have any competing interest.

\section{References}

[1] Belton B, Karim M, Thilsted S, Jahan KM, Collis W and Phillips M. (2011). Review of aquaculture and fish consumption in Bangladesh. Studies and Reviews 53, Penang; The world fish center, 76.

[2] Hassan MR, Acharjee M, Das E, Das KK, Ahmed T, Akond MA, Fatema KK and Noor R. (2015). Microbiological study of sea fish samples collected from local markets in Dhaka city. International Food Research Journal, 20, $1491-1495$.

[3] Noor R, Acharjee M, Ahmed T, Das KK, Paul L, Munshi SK, Urmi NJ, Rahman F and Alam MJ. (2013). Microbiological analysis of major sea fish collected from local markets in Dhaka city, Bangladesh. Journal Microbiology Biotechnology and Food Science, 2, 2420-2430

[4] Bogard JR Thilsted S and Marks GC. (2015) Nutrient composition of important fish species in Bangladesh and potential distribution to recommended nutrient intakes. Journal of Food Component Analysis, 42(1), 120 -133.

[5] Trust TJ and Sparrow RAH. (1974). The bacterial flora in the alimentary tract of freshwater salmonid fish. Canadian Journal of Microbiology, 20, 1219-1228.

[6] Jay JM, Loessner MJ and Golden DA. (2005). Modern food microbiology, Food Science Text Series, Springer, New York, 321 - 324

[7] Shinkafi SA and Ukwaja VC. (2010). Bacteria Associated with fresh Tilapia fish (Oreochromis niloticus) sold at Sokoto central market in Sokoto, Nigeria. Nigerian Journal of Basic and Applied Sciences, 18 (2), $217-221$.

[8] Mobin SMA, Chowdhury MBR, Islam MS and Uddin MN. (2001). Status of bacterial flora in the intestine of two freshwater fish. Bangladesh Journal of Life Sciences, 13(1and 2), 149-155.

[9] Das MF, Hafiz MK, Ahmed P and Parveen S. (2007.) Microbiological analysis of some raw fish samples. Bangladesh Journal of Microbiology, 24(1), 67-69. 
[10] FRSS (Fisheries Resources Survey Systems). (2014). Fishery statistics yearbook of Bangladesh, 2012-13; DOF (Department of Fisheries), Bangladesh.

[11] Cheesbrough M (2006). Medical Laboratory Manual. Tropical Health Technology, Low priced Edition. Doddington, Cambridgeshire, England, 20-35.

[12] Roquia F, Hussain Q, Nadeem, SG and Hakim ST. (2014). Bacteriological analysis of Nile Tilapia, fish (Oreochromis niloticus). Journal of Biological Research and Applied Sciences, 5(1), 30-35.

[13] Mahmuda, B, Abu, TAA, Degu, GI, Kato, CD and Mukalazi J. (2010). A comparative microbiological assessment of five types of selected fish collected from two different markets. Advances in Biological Research, 4(5), 259-265.

[14] Jha P, Roy RP and Barat S. (2010). Application of sensory and microbial analysis to assess quality of fish in Silliguri city of western Bengal, India. Journal of Environmental Biology, 31(5), 587-594.

[15] Buchanan RE and Gribbons NE. (1974). Bergey's Manual of Determinative Bacteriology (8th edition). Williams and Wilkins Co. Baltimore USA.

[16] Enabulele SA and Uraih N. (2009). Enterohaemorrhagic Escherichia coli 0157:H7 prevalence in meat and vegetables sold in Benin City, Nigeria. African Journal of Microbiology Research, 3(5), 276-279.

[17] Sobukola OP, Awonorin OS, Idowu AM and Bamiro OF. (2009). Microbial profile and critical control points during processing of 'robo' snack from melon seed (Citrullus lunatus thumb) in Abeokuta, Nigeria. African Journal of Biotechnology, 8(10), 2385-2388.

[18] Clarence SY, Obinna CN and Shalom NC. (2009). Assessment of bacteriological quality of ready to eat food (Meat pie) in Benin City metropolis, Nigeria. African Journal Microbial Research, 3(6), 390-395.

[19] Oyeleke SB. (2009). Microbial assessment of some commercially prepared yoghurt retailed in Minna, Niger State. African Journal of Microbiology Research, 3(5), 245-248.

[20] Okonko IO, Ogun AA, Adejoye OD, Ogunjobi AA, Nkang AO and Adebayo-Tayo BC. (2009). Hazards analysis critical control points (HACCP) and microbiology qualities of sea-foods as affected by Handler's Hygiene in Ibadan and Lagos, Nigeria. African Journal of Food Science, 3(1), 035-050.

[21] Okonko IO, Donbraye E and Babatunde SOI. (2009). Microbiological quality of seafood processors and water used in two different sea processing plants in Nigeria. Electronic Journal of Environmental, Agricultural and Food chemistry, 8(8), 621-629.

[22] Okonko IO, Ogunjobi AA, Adejoye OD, Ogunnusi TA and Olasogba MC. (2009). Comparative studies and microbial risk assessment of different water samples used for processing frozen sea-foods in Ijoraolopa, Lagos State, Nigeria. African Journal of Biotechnology, 7(16), 2902-2907.

[23] Okonko IO, Ogunnusi TA, Ogunjobi AA, Adedeji AO, Adejoye OD, Babalola ET and Ogun AA. (2009). Microbial studies on frozen shrimps processed in Ibadan and Lagos, Nigeria. Scientific Research and Essay, 3(11), 537-546.

[24] Talaro K and Talaro A. (2006). Foundation in microbiology. W.M.C Brown Publisher, Dubuque, 781 - 783.

[25] Schroeder CM, Naugle AL, Schlosser WD, Hogue AT, Angulo FJ, Rose JS, Ebel ED, Disney WT, Holt KG and Goldman DP. (2005). Estimate of illnesses from Salmonella enteritidis in eggs, United States, 2000. Emerging Infectious Diseases, 11(1), 113.

\section{How to cite this article}

Alagoa KJ, Daworiye P, Enaregha E, Ipiteikumoh B and Agwu R. (2018). Surface bacterial flora of Tilapia (Oreochromis niloticus) in open markets of Yenagoa, Bayelsa state. GSC Biological and Pharmaceutical Sciences, 4(2), 24-30. 